\title{
Effect of Supplemental Oregano Essential Oils in Diets on Production Performance and Relatively Intestinal Parameters of Laying Hens
}

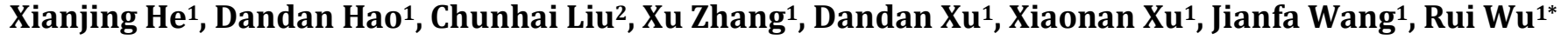 \\ ${ }^{1}$ College of Animal Science and Veterinary Medicine, Heilongjiang Bayi Agricultural University, Daqing, China \\ ${ }^{2}$ Beijing Feedig Feed Science and Technology Co., Ltd., Beijing, China \\ Email: xianjinghe@126.com,wjflw@sina.com, ^fuhewu@126.com
}

How to cite this paper: He, X.J., Hao, D.D., Liu, C.H., Zhang, X., Xu, D.D., Xu, X.N., Wang, J.F. and Wu, R. (2017) Effect of Supplemental Oregano Essential Oils in Diets on Production Performance and Relatively Intestinal Parameters of Laying Hens. American Journal of Molecular Biology, 7, 73-85.

http://dx.doi.org/10.4236/ajmb.2017.71006

Received: August 29, 2016

Accepted: January 19, 2017

Published: January 22, 2017

Copyright $\odot 2017$ by authors and Scientific Research Publishing Inc. This work is licensed under the Creative Commons Attribution International License (CC BY 4.0).

http://creativecommons.org/licenses/by/4.0/

cc) (i) Open Access

\begin{abstract}
This study was designed to investigate the effects of dietary oregano essential oils on 150 30-week-old Hy-Line Layers' productive performance, egg quality characteristics, cecal microbiota, digestive enzyme activities, mucosa structure of the duodenum and jejunum and glucose and small peptides transporters expression in the duodenum and jejunum. All hens were allocated into one of five different groups: negative control (NC; basal diet only), antibiotics control (CS; basal diet plus $100 \mathrm{mg} / \mathrm{kg}$ of $10 \%$ colistin sulfate) and treatments I, II, and III (basal diet supplemented with 50, 100 and $150 \mathrm{mg} / \mathrm{kg}$ oregano essential oils, respectively). The results showed that the laying rate, average egg weight, feed conversion ratio and the activities of amylase and trypsin were significantly improved by a diet supplemented with $100 \mathrm{mg} / \mathrm{kg}$ oregano essential oils $(\mathrm{P}<0.01)$. The addition of oregano essential oils increased the number of intestinal Bifidobacterium and Lactobacillus significantly $(\mathrm{P}<0.01)$, whereas the number of intestinal Escherichia coli and Salmonella was significantly (P $<0.01)$ decreased. The addition of $100 \mathrm{mg} / \mathrm{kg}$ oregano essential oils increased duodenum villus height $(\mathrm{P}>0.05)$, significantly increased duodenum villus-height-tocrypt-depth ratios $(\mathrm{P}<0.01)$ and decreased crypt depth in the duodenum $(\mathrm{P}<0.05)$. Furthermore, the glucose transporter 2 (GLUT2), peptide transporter 1 (PepT1) and sodium-glucose cotransporter 1 (SGLT1) gene expression levels in the duodenum and jejunum were significantly increased in laying hens on a diet supplemented with $100 \mathrm{mg} / \mathrm{kg}$ oregano essential oils $(\mathrm{P}<0.01)$. However, egg weight, relative eggshell weight, yolk index and Haugh unit value were not significantly affected by the addition of oregano essential oils $(\mathrm{P}>0.05)$.
\end{abstract}

\section{Keywords}

Laying Hens, Oregano Essential Oils, Intestinal Morphology, Intestinal Function 


\section{Introduction}

It has been widely recognized that the presence of intestinal diseases, such as bacterial and viral infections, imbalances of the gut flora and coccidiosis, can affect nutrient utilization adversely and reduce the production performance of laying hens. To prevent intestinal diseases and improve production performance, a variety of feed additives, especially antibiotics, have been widely used in the poultry industry for several decades. The use of antibiotics in poultry feed has led to growing concern about drug residues and the development of antimicrobial resistance [1] [2]. Since the implementation of a complete ban on antibiotic feed additives by the European Union in 2006, finding suitable alternatives to antibiotics has become more important [3]. The alternatives most frequently used as feed additives for increasing performance and general health are prebiotics, probiotics, organic acids and phytogenic additives. Phytogenic additives, which are found in a wide variety of plants, spices and their derivatives, positively affect the quality of products, production performance and animal health and have been recognized as safe in the food industry [3].

Oregano (Origanum vulgare L.) essential oils, a phytogenic additive, are an aromatic plant that is indigenous to the Mediterranean region. It has been reported that oregano essential oils has many diverse biological activities in vitro and in vivo, including antimicrobial, antioxidant and antifungal effects, which mainly depended on the carvacrol and thymol compositions [4] [5] [6] [7]. Several in vivo studies on intestinal digestion have been conducted on the performance, cecal flora, digestive enzyme activities and intestinal morphology of poultry with oregano essential oils or combinations [8] [9] [10] [11], but the results have been variable and incomplete. Roofchaee found that OEO (oregano essential oil) exerted growth promoting effects and also displayed potent antibacterial effects against cecal $E$. coli. [8]. Hashemipour discovered that feed supplementation with thymol and carvacrol has a positive effect on broilers. It enhanced performance, increased antioxidant enzyme activities, retarded lipid oxidation, and enhanced digestive enzyme activities [9]. Radwan also found that oregano or thyme at $1.0 \%$ can improve productive performance [11]. The effects and mechanisms of oregano essential oils on intestinal digestive and absorption functions in laying hens have not been thoroughly investigated. Therefore, this study was conducted to investigate the effects of oregano essential oils as a laying hen feed supplement on the production performance, egg quality, cecal flora, morphological parameters, intestinal digestive enzyme activities and nutrition transport.

\section{Materials and Methods}

\subsection{Animals, Housing and Diets}

Experiments were conducted in accordance with the guiding principles in the use of animals adopted by the Chinese Association for Laboratory Animal Sciences. The study protocol was approved by the Ethics Committee on the Use and Care of Animals, Heilongjiang Bayi Agricultural University (Daqing, China). One hundred and fifty 30week-old Hy-Line Layers were purchased from a local poultry farm, at the peak egg production period, and were housed alone in cages. The hens were randomly divided into five dietary treatments with thirty replicates. The hens were raised in a naturally 
ventilated, open-side experimental house, and the environmental temperature of the room ranged from $20^{\circ} \mathrm{C}$ to $27^{\circ} \mathrm{C}$. The relative humidity was between $45 \%$ and $60 \%$, with 16 hours of light from 6 am to $10 \mathrm{pm}$, which followed the commercial recommendations.

The experiment lasted for 49 days after a 7-day adaptation period. The ingredient and nutrient levels of the basal diet present in Table 1 met the NRC recommendations (NRC, 1994). All hens were allocated into one of five different groups: negative control (NC; basal diet only), antibiotics control (CS; basal diet plus $100 \mathrm{mg} / \mathrm{kg}$ of $10 \%$ colistin sulfate) and treatments I, II, and III (basal diet supplemented with 50, 100 and 150 $\mathrm{mg} / \mathrm{kg}$ oregano essential oils, respectively). The oregano essential oils components were identified by gas chromatography/mass spectrometry (GC/MS), and analysis by GC/MS with a chromatograph interfaced to a mass spectrometer (HP 5971, USA), present on Table 2. It is yellow fine granules which is packaged with microcapsule. The hens were quantitatively fed two times a day at the same time with free access to feed and water. All kinds of feed supplements used in the experiment were homogenously incorporated into the feed mixture in the feed mill.

Table 1. Ingredients and nutrient levels of the basal diet (air dry basis, \%).

\begin{tabular}{|c|c|}
\hline Items & Content \\
\hline \multicolumn{2}{|l|}{ Ingredients } \\
\hline Corn & 61.52 \\
\hline Soybean meal & 18.86 \\
\hline Cottonseed meal & 6.29 \\
\hline Soybean oils & 1.01 \\
\hline Limestone & 8.43 \\
\hline $\mathrm{NaCl}$ & 0.47 \\
\hline Lysine & 0.03 \\
\hline DL-Methionine & 0.40 \\
\hline Choline chloride (50\%) & 0.28 \\
\hline $\mathrm{CaHPO}_{4}$ & 1.71 \\
\hline Premix $^{\mathrm{a}}$ & 1.00 \\
\hline Total & 100.00 \\
\hline \multicolumn{2}{|l|}{ Nutrient levels } \\
\hline Metabolic energy/(MJ/kg) & 2.79 \\
\hline Crude protein & 15.9 \\
\hline Total phosphorus & 0.62 \\
\hline Available phosphorus & 0.40 \\
\hline Methionine + Cysteine & 0.63 \\
\hline Methionine & 0.39 \\
\hline Lysine & 0.71 \\
\hline Calcium & 3.49 \\
\hline
\end{tabular}

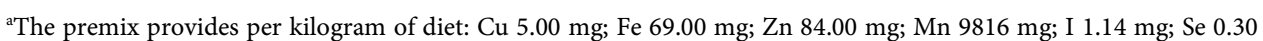
mg; VA 15,000 IU; VD 33,000 IU; VE 25.5 mg; VK 32.1 mg; VB1 2.4 mg; VB2 9 mg; VB6 5.1 mg; VB12 0.02 mg; calcium pantothenate $12 \mathrm{mg}$; niacin $48 \mathrm{mg}$; folic acid $1.2 \mathrm{mg}$; biotin $0.06 \mathrm{mg}$; roxarsone $50 \mathrm{mg}$; salinomycin $90 \mathrm{mg}$. 
Table 2. Composition of essential oils of oregano obtained by GC/MS.

\begin{tabular}{|c|c|}
\hline Constituent & Yield (\%) \\
\hline$\alpha$-Pinene & 0.32 \\
\hline$\beta$-Pinene & 0.15 \\
\hline$\beta$-Myrcene & 1.27 \\
\hline$\alpha$-Thujene & 0.79 \\
\hline Camphene & 0.33 \\
\hline$\alpha$-Terpinene & 1.01 \\
\hline$\gamma$-Terpinene & 1.17 \\
\hline D-Limonene & 0.21 \\
\hline Terpinen & 0.15 \\
\hline Methyl thymyl ether & 0.72 \\
\hline Myristicacid & 0.54 \\
\hline 2-Isopropyholuene & 1.38 \\
\hline 2-Carene & 0.59 \\
\hline Caryophyllene & 3.70 \\
\hline Germacrene D & 0.26 \\
\hline$\alpha$-Farnesene & 0.96 \\
\hline Sabinene & 0.58 \\
\hline cis- $\beta$-Terpinene & 0.49 \\
\hline Thymol & 7.29 \\
\hline Terpinolene & 0.17 \\
\hline$\delta$-Cadinene & 0.12 \\
\hline 3-Octanol & 0.23 \\
\hline p-Cymene & 3.90 \\
\hline Carvacrol & 73.06 \\
\hline Borneol & 0.27 \\
\hline
\end{tabular}

\subsection{Productive Performance and Egg Quality}

During the trial, egg production and egg weight (EW) were recorded daily by replicate, and egg conversion was calculated. Feed intake was recorded weekly, and egg mass, egg production, and feed conversion ratio (grams of feed consumed per grams of egg produced, FCR) were calculated. Deaths were recorded when they occurred.

On the last week of trial, 30 eggs were randomly collected from each replicate to determine the egg shape index, yolk index, yolk ratio, eggshell ratio and Haugh units [12]. Initially, the egg samples were weighed individually, and were stored at $4^{\circ} \mathrm{C}$. Afterward, the egg quality parameters were calculated using routine methods.

\subsection{Collection of Samples}

At the end of the experiment ( 49 d), 6 hens per treatment ( 2 hens per replicate) were randomly selected and euthanized by cervical dislocation. Then, the whole intestinal tract was immediately excised and put in sterile bags, placed on ice to take to the laboratory for further sampling. 


\subsection{Microbial Analysis}

The two ceca were longitudinally opened using a pair of sterile scissors, and digesta samples $(1 \mathrm{~g})$ were collected after both ceca were cut down. The samples were serially diluted from 10-1 to 10-7 in sterilized physiological saline solution. Selective agar media was used for enumeration of Escherichia coli (MacConkey Agar, Hopebio, Qingdao, China), Salmonella (Salmonella Shigella Agar, Hopebio, Qingdao, China), Lactobacillus (Lactobacillus Selection, Hopebio, Qingdao, China), and Bifidobacterium (Bismuth Sulfite Agar, Hopebio, Qingdao, China) by conventional microbiological techniques. Briefly, triplicate plates were inoculated with $1 \mathrm{~mL}$ samples, and three suitable dilutions were plated for each medium. Escherichia coli and Salmonella were enumerated on agar after aerobic incubation at $37^{\circ} \mathrm{C}$ for $18-24 \mathrm{~h}$. Lactobacillus and Bifidobacterium were enumerated after anaerobic chamber incubation at $37^{\circ} \mathrm{C}$ for $48 \mathrm{~h}$. In addition, the numbers of colony-forming units in the duplicate plates were averaged. The cecal contents were denoted as base 10 log colony-forming units per gram (cfu/g).

\subsection{Digestive Enzymes Activity Assay}

The intestinal digesta samples were collected by scraping the tract gently and weighed. Then, the digesta samples were immediately placed into liquid nitrogen and stored at $-80^{\circ} \mathrm{C}$ until further analysis. Thawed digesta samples were diluted $10 \times$ using ice cold PBS ( $\mathrm{pH} 7.0$ ) based on the sample weight. After being fully homogenized, the samples were centrifuged at $2500 \mathrm{rpm}$ for $8-10 \mathrm{~min}$, and the supernatants were stored at $-20^{\circ} \mathrm{C}$ for enzyme assays.

Amylase, lipase and trypsin activity were detected with commercial kits (Nanjing Jiancheng Bioengineering Institute, Nanjing, China) via spectrophotometry (UV2102C, UNICO, Shanghai, China), a simplified turbidimetric assay and ethyl N-benzoyl-L-argininate hydrochloride (BAEE) as a substrate were performed according to the manufacturer's instructions, respectively. Enzyme activity was described using enzymatic activity units $(\mathrm{U})$ per gram.

\subsection{Intestinal Morphology}

Segments $(1 \mathrm{~cm})$ of the duodenum (from the gizzard to pancreatic), jejunum (between the entry point of bile ducts and Meckel's diverticulum) and ileum $(5 \mathrm{~cm}$ proximal to the ileocecal junction) were all removed from the whole intestinal tract. The samples were fixed in $4 \%$ formalin after washing with cold physiological saline. Each sample was embedded in paraffin wax, and tissue sections $(5 \mu \mathrm{m})$ were cut before staining with hematoxylin and eosin, and villus height (from the tip to the villus crypt junction) and crypt depth (from the valley between adjacent villi to the basolateral membrane) were examined by optical microscopy with a digital video camera (B5 Digital, Motic, Xiamen, China). Morphological indices were measured using stereological image software (Med6.0, Motic, Xiamen, China). And morphological indices data were analyzed with SPSS 17.0 software.

\subsection{Real-Time PCR}

Segments of the duodenum and jejunum were opened longitudinally and rinsed with 
ice cold normal saline, scraped with glass slides, the intestinal mucosa frozen in liquid nitrogen, and stored at $-80^{\circ} \mathrm{C}$. Total RNA was extracted from intestinal tissues using a QIAGEN RNeasy Mini Kit (Hilden, Germany), according to the manufacturer's instructions. The purity and concentration of the total RNA were measured at 260/280 nm with a SmartSpecTMPlus Spectrophotometer (BIO-RAD, California, USA). The cDNA was synthesized from $1 \mu \mathrm{g}$ of total RNA using a PrimeScript ${ }^{\circ}$ RT Reagent Kit with gDNA Eraser (Takara, Dalian, China) according to the manufacturer's protocols. The products ( $\mathrm{cDNA}$ ) were stored at $-20^{\circ} \mathrm{C}$ for RT-PCR. The specific primers for sodium-glucose cotransporter 1 (SGLT1), glucose transporter 2 (GLUT2), peptide transporter 1 (PepT1) and $\beta$-actin(ACTB) were designed using Primer 5.0 (Table 3). PCR amplification was conducted, and the products were checked on $1 \%$ agarose gels, extracted, cloned into the pMD18-T vector (Takara) and sequenced. A standard curve was made of serially diluted plasmid by plotting threshold cycle values. RT-PCR was performed using SYBR ${ }^{\oplus}$ Premix Ex Taq ${ }^{\mathrm{Tm}}$ (Takara) and $1 \mu \mathrm{L}$ cDNA on a Line-gene $\mathrm{K}$ Real-Time PCR Detection System with software (Bioer Technology, Hangzhou, China) in $50 \mu \mathrm{L}$ reactions. Thermal cycling was performed with the following conditions: $94^{\circ} \mathrm{C}$ for $3 \mathrm{~min}$ and $45 \mathrm{cycles}$ of $94^{\circ} \mathrm{C}$ for $15 \mathrm{~s}, 57^{\circ} \mathrm{C}$ for $30 \mathrm{~s}$, and a final step of $72^{\circ} \mathrm{C}$ for $20 \mathrm{~s}$. Each sample was measured for three replicates and normalized by using $\beta$-actin. The samples' copy number was calculated by interpolating the threshold cycle values with the standard curve.

\subsection{Statistical Analysis}

All data were analyzed with SPSS 17.0 software (SPSS Inc, Chicago, IL, USA). The statistically significant differences in treatment means were evaluated using one-way ANOVA, and a multiple comparison (Duncan)test was conducted with significant treatment means. $\mathrm{P}<0.05$ was considered as the significant level and $\mathrm{P}<0.01$ as extremely significant. Values are expressed as the means \pm standard deviation.

\section{Results}

\subsection{Production Performance}

The effects of oregano essential oils supplementation in the diet of laying hens on the production performance of five different groups (NC, CS, I, II and III) are presented in

Table 3. List of primers used for real-time PCR.

\begin{tabular}{cccc}
\hline Target & $\begin{array}{c}\text { Accession } \\
\text { No. }\end{array}$ & Primer sequence (5'-3') & Amplicon length (bp) \\
\hline \multirow{2}{*}{ SGLT1 } & XM_415247 & $\begin{array}{r}\text { F: CCTGGAATGATCAGCCGAAT } \\
\text { R: ACCTCGTAGACCATTTGGCATAA }\end{array}$ & $150 \mathrm{bp}$ \\
& & F: GGCGTTGGAGTGGTGAACAC & $150 \mathrm{bp}$ \\
GLUT2 & NM_207178 & R: GAACTGGCTCAGGAGCACAAG & \\
& & F: CCCCAATTCTCAGAGCTCAAGA & $150 \mathrm{bp}$ \\
PepT1 & AY029615 & R: TGCCTTGCGGTTGACTTT & \\
& & F: GTTGACAATGGCTCCGGTAT & $150 \mathrm{bp}$ \\
\hline
\end{tabular}


Table 4. The addition of $100 \mathrm{mg} / \mathrm{kg}$ oregano essential oils significantly increased the laying rate $(\mathrm{P}<0.01)$, average egg weight, and improved feed conversion ratio $(\mathrm{P}<$ $0.01)$ compared with the NC and CS groups. However, the daily intake was statistically similar among dietary treatments $(\mathrm{P}>0.05)$. Morbidity and mortality were nil in all treatments.

\subsection{Egg Quality}

Egg weight, eggshell ratio, yolk index and Haugh units were not influenced significantly by oregano treatments compared with the NC and CS groups $(\mathrm{P}>0.05)$ (Table 5). However, $50 \mathrm{mg} / \mathrm{kg}$ oregano essential oils diet increased the percentage of yolk ratio and egg shape index $(\mathrm{P}<0.05)$ compared with the CS group, but there was no significant difference in oregano treatments compared with the NC group $(\mathrm{P}>0.05)$.

\subsection{Cecal Microflora}

The results of cecal flora analysis are summarized in Table 6. In the cecal digesta, Bifidobacterium and Lactobacillus counts were significantly $(\mathrm{P}<0.01)$ increased for hens fed $100 \mathrm{mg} / \mathrm{kg}$ of oregano essential oils versus other groups, whereas Escherichia coli and Salmonella counts were significantly $(\mathrm{P}<0.01)$ decreased, ever lower than in the CS group. The present study demonstrated that supplementation of oregano essential oils has a positive effect on intestinal microbiology.

Table 4. Effect of oregano essential oils supplementation on performance of laying hens.

\begin{tabular}{cccccc}
\hline & \multicolumn{5}{c}{ Groups } \\
\cline { 2 - 6 } Parameter & NC & CS & I & II & III \\
\cline { 2 - 6 } & $91.97 \pm 3.35^{\mathrm{Bb}}$ & $92.43 \pm 2.51^{\mathrm{Bbc}}$ & $94.50 \pm 2.69^{\mathrm{ac}}$ & $96.88 \pm 1.55^{\mathrm{Aa}}$ & $95.09 \pm 1.48^{\mathrm{a}}$ \\
Laying rate (\%) & $61.11 \pm 1.34^{\mathrm{b}}$ & $60.14 \pm 1.56^{\mathrm{Bab}}$ & $62.65 \pm 1.07^{\mathrm{Aab}}$ & $63.23 \pm 2.12^{\mathrm{Aa}}$ & $61.66 \pm 1.81^{\mathrm{ab}}$ \\
Average egg weight $(\mathrm{g})$ & $61.63 \pm 3.98$ & $141.98 \pm 3.89$ & $138.89 \pm 4.58$ & $141.29 \pm 3.40$ & $142.55 \pm 2.19$ \\
$\begin{array}{c}\text { Daily feed intake (g) } \\
\text { Feed conversion ratio } \\
(\mathrm{g} \text { feed/g egg) }\end{array}$ & $2.53 \pm 0.17^{\mathrm{B}}$ & $2.54 \pm 0.12^{\mathrm{B}}$ & $2.35 \pm 0.12^{\mathrm{A}}$ & $2.31 \pm 0.12^{\mathrm{A}}$ & $2.43 \pm 0.10^{\mathrm{AB}}$ \\
\hline
\end{tabular}

Values on the same line sharing a different superscript $\mathrm{a}, \mathrm{b}, \mathrm{c}$ are significantly different at $\mathrm{P}<0.05$. Values on the same line sharing a different superscript A, B, C, D are significantly different at $\mathrm{P}<0.01$. ${ }^{*} \mathrm{NC}$ (no treatment), CS ( $10 \%$ colistin sulfate, $100 \mathrm{mg} / \mathrm{kg}$ diet), I (oregano essential oils, $50 \mathrm{mg} / \mathrm{kg}$ diet), II (oregano essential oils, $100 \mathrm{mg} / \mathrm{kg}$ diet), and III (oregano essential oils, $150 \mathrm{mg} / \mathrm{kg}$ diet). Same as below.

Table 5. Effect of oregano essential oils supplementation on egg quality parameters of laying hens.

\begin{tabular}{cccccc}
\hline & \multicolumn{5}{c}{ Groups } \\
Parameter & NC & CS & I & II & III \\
\cline { 2 - 6 } & $64.18 \pm 4.31^{\mathrm{ab}}$ & $62.62 \pm 5.98^{\mathrm{ab}}$ & $60.90 \pm 4.54^{\mathrm{a}}$ & $65.75 \pm 5.60^{\mathrm{b}}$ & $64.34 \pm 4.23^{\mathrm{ab}}$ \\
\hline Egg weight (g) & $9.86 \pm 1.45$ & $9.75 \pm 0.78$ & $10.22 \pm 1.08$ & $10.67 \pm 1.79$ & $10.43 \pm 1.43$ \\
Eggshell ratio (\%) & $32.84 \pm 1.38^{\mathrm{ab}}$ & $31.37 \pm 0.86^{\mathrm{bc}}$ & $34.16 \pm 3.33^{\mathrm{Aa}}$ & $33.00 \pm 2.93^{\mathrm{ab}}$ & $30.42 \pm 1.53^{\mathrm{Bc}}$ \\
Yolk ratio (\%) & $128.78 \pm 0.06^{\mathrm{ab}}$ & $126.89 \pm 0.05^{\mathrm{b}}$ & $132.67 \pm 0.06^{\mathrm{a}}$ & $130.56 \pm 0.03^{\mathrm{ab}}$ & $130.56 \pm 0.04^{\mathrm{ab}}$ \\
Egg shape index (\%) & $131.40 \pm 1.15$ & $40.92 \pm 10.88$ & $41.28 \pm 8.00$ & $41.76 \pm 3.56$ & $43.68 \pm 4.95$ \\
Yolk index (\%) & $48.91 \pm 2.15^{\mathrm{ab}}$ & $80.37 \pm 3.42^{\mathrm{ab}}$ & $76.84 \pm 1.31^{\mathrm{a}}$ & $78.80 \pm 2.39^{\mathrm{ab}}$ & $81.79 \pm 3.58^{\mathrm{b}}$ \\
Haugh units (\%) & 78.95 & & &
\end{tabular}


Table 6. Effect of oregano essential oils supplementation on cecum flora of laying hens (cfu/g).

\begin{tabular}{cccccc}
\hline \multirow{2}{*}{ Microflora } & \multicolumn{5}{c}{ Groups } \\
\cline { 2 - 6 } & NC & CS & I & II & III \\
\hline Lactobacilli & $6.09 \pm 0.14^{\mathrm{CD}}$ & $6.20 \pm 0.16^{\mathrm{ADb}}$ & $6.42 \pm 0.11^{\mathrm{Aa}}$ & $7.09 \pm 0.11^{\mathrm{B}}$ & $6.88 \pm 0.05^{\mathrm{B}}$ \\
Bifidobacteria & $7.26 \pm 0.09^{\mathrm{C}}$ & $7.53 \pm 0.12^{\mathrm{A}}$ & $7.56 \pm 0.07^{\mathrm{A}}$ & $8.02 \pm 0.15^{\mathrm{B}}$ & $7.67 \pm 0.08^{\mathrm{A}}$ \\
Escherichia coli & $7.02 \pm 0.07^{\mathrm{C}}$ & $6.39 \pm 0.07^{\mathrm{Aa}}$ & $6.40 \pm 0.07^{\mathrm{Aa}}$ & $6.21 \pm 0.07^{\mathrm{Bb}}$ & $6.25 \pm 0.06^{\mathrm{ABb}}$ \\
Salmonella & $5.80 \pm 0.12^{\mathrm{C}}$ & $5.3 \pm 0.10^{\mathrm{B}}$ & $5.04 \pm 0.06^{\mathrm{Aa}}$ & $4.80 \pm 0.08^{\mathrm{Ab}}$ & $4.90 \pm 0.10^{\mathrm{A}}$ \\
\hline
\end{tabular}

\subsection{Intestinal Morphology}

The morphology data indicated that the addition of $100 \mathrm{mg} / \mathrm{kg}$ oregano essential oils increased the villus height $(\mathrm{P}>0.05)$ and villus-height-to-crypt-depth ratios $(\mathrm{P}<0.01)$ in the duodenum compared with the NC group (Table 7). The duodenum crypt depth was decreased by $100 \mathrm{mg} / \mathrm{kg}$ oregano essential oils supplementation compared with the NC group. However, for the jejunum, after the addition of oregano essential oils, there was a slight effect on villus height, crypt depth or villus-height-to-crypt-depth ratios in comparison with the $\mathrm{NC}$ and $\mathrm{CS}$ groups $(\mathrm{P}>0.05)$.

\subsection{Digestive Enzyme Activities}

The effects of oregano essential oils supplementation on intestinal digestive enzyme activities in laying hens are shown in Table 8 . The addition of $100 \mathrm{mg} / \mathrm{kg}$ oregano essential oils on hens produced a significant increase in the activities of amylase and trypsin relative to the NC group $(\mathrm{P}<0.01)$, and amylase activity was higher $(\mathrm{P}<0.05)$ in the group II than in the CS group. Lipase activity was slightly increased by dietary treatments $(P>0.05)$. The results indicated that supplementation with oregano essential oils improved the activities of digestive enzyme activities and may improve the digestion of nutrients in the small intestine.

\subsection{Glucose and Peptide Transport Gene Expression}

The effect of oregano essential oils supplementation on GLUT2, PepT1 and SGLT1 mRNA expression data are presented in Table 9. A significant increase $(\mathrm{P}<0.01)$ in the GLUT2, PepT1 and SGLT1 gene expression could be observed in group II, which received the diet containing $100 \mathrm{mg} / \mathrm{kg}$ oregano essential oils, in the duodenum and jejunum. The increase in these parameters corresponds to an increase in nutrition absorption.

\section{Discussion}

Oregano essential oils has been developed as an antibiotic alternative in the poultry industry partly because of biological activities, such as antimicrobial, antioxidant, antiseptic and antiparasitic activity. Some researchers have obtained positive results concerning the efficacy of oregano essential oils on the performance in poultry, which is in agreement with our results. Radwan et al. have reported that the use of $1.0 \%$ oregano in the diet increased egg production and egg weight and improved feed conversion of hens [11]. Roofchaee et al. obtained a similar result in that dietary oregano essential oils 
Table 7. Effect of oregano essential oils supplementation on the intestinal morphological parameters of laying hens.

\begin{tabular}{cccccc}
\hline Parameters & \multicolumn{5}{c}{ Groups } \\
\hline & NC & CS & I & II & III \\
\hline Duodenum & & & & & \\
Villus height $(\mu \mathrm{m})$ & $385.99 \pm 5.88$ & $389.92 \pm 4.27$ & $386.94 \pm 2.05$ & $394.10 \pm 4.36$ & $393.30 \pm 5.16$ \\
Crypt depth $(\mu \mathrm{m})$ & $34.48 \pm 0.47^{\mathrm{b}}$ & $33.40 \pm 0.98^{\mathrm{ab}}$ & $33.35 \pm 0.58^{\mathrm{ab}}$ & $33.18 \pm 0.37^{\mathrm{a}}$ & $33.53 \pm 0.60^{\mathrm{ab}}$ \\
$\begin{array}{c}\text { Villus height/crypt } \\
\text { depth }\end{array}$ & $11.20 \pm 0.28^{\mathrm{Bb}}$ & $11.68 \pm 0.39^{\mathrm{a}}$ & $11.60 \pm 0.15^{\mathrm{ab}}$ & $11.88 \pm 0.04^{\mathrm{Aab}}$ & $11.73 \pm 0.30^{\mathrm{a}}$ \\
$\begin{array}{c}\text { Jejunum } \\
\text { Villus height }(\mu \mathrm{m})\end{array}$ & $319.05 \pm 3.17$ & $322.02 \pm 7.30$ & $317.43 \pm 5.97$ & $330.99 \pm 17.77$ & $327.86 \pm 8.80$ \\
$\begin{array}{c}\text { Crypt depth }(\mu \mathrm{m}) \\
\text { Villus height/crypt } \\
\text { depth }\end{array}$ & $29.52 \pm 0.83$ & $29.28 \pm 0.68$ & $29.04 \pm 0.37$ & $28.27 \pm 0.94$ & $28.60 \pm 1.01$ \\
& $10.81 \pm 0.33$ & $11.00 \pm 0.33$ & $10.93 \pm 0.33$ & $11.73 \pm 0.96$ & $11.47 \pm 0.32$ \\
\hline
\end{tabular}

Table 8. Effect of oregano essential oils supplementation on the digestive enzyme activities in the small intestinal contents of laying hens (U/mg protein).

\begin{tabular}{cccccc}
\hline \multirow{2}{*}{ Enzyme } & \multicolumn{5}{c}{ Groups } \\
\cline { 2 - 6 } & $\mathrm{NC}$ & $\mathrm{CS}$ & $\mathrm{I}$ & $\mathrm{II}$ & $\mathrm{III}$ \\
\hline Amylase & $4.65 \pm 0.10^{\mathrm{A}}$ & $4.73 \pm 0.16^{\mathrm{b}}$ & $4.64 \pm 0.08^{\mathrm{A}}$ & $4.99 \pm 0.13^{\mathrm{Ba}}$ & $4.76 \pm 0.14^{\mathrm{b}}$ \\
Lipase & $75.60 \pm 0.46$ & $75.62 \pm 0.46$ & $75.91 \pm 0.35$ & $76.11 \pm 0.15$ & $76.03 \pm 0.17$ \\
Trypsin & $1964.26 \pm 69.77^{\mathrm{A}}$ & $2074.87 \pm 94.68^{\mathrm{AB}}$ & $1967.44 \pm 47.54^{\mathrm{A}}$ & $2160.10 \pm 80.22^{\mathrm{B}}$ & $2042.31 \pm 71.41^{\mathrm{AB}}$ \\
\hline
\end{tabular}

Table 9. Effect of oregano essential oils supplementation on the GLUT2, SGLT1, and PepT1 gene expression in the intestines of laying hens.

\begin{tabular}{cccccc}
\hline \multirow{2}{*}{ Parameters } & \multicolumn{5}{c}{ Groups } \\
\cline { 2 - 5 } & NC & CS & I & II & III \\
\hline 1-Duodenum & & & & \\
GLUT2 (AU) & $1.00 \pm 0.59^{\mathrm{Aa}}$ & $1.56 \pm 0.36^{\mathrm{Aac}}$ & $2.05 \pm 0.92^{\mathrm{Aac}}$ & $6.02 \pm 0.67^{\mathrm{B}}$ & $2.33 \pm 0.18^{\mathrm{Abc}}$ \\
SGLT1 (AU) & $1.00 \pm 0.16^{\mathrm{Aa}}$ & $3.08 \pm 0.95^{\mathrm{CDb}}$ & $1.90 \pm 0.45^{\mathrm{ACa}}$ & $6.19 \pm 0.53^{\mathrm{B}}$ & $3.36 \pm 0.32^{\mathrm{Db}}$ \\
PepT1 (AU) & $1.00 \pm 0.26^{\mathrm{Aa}}$ & $3.56 \pm 0.92^{\mathrm{Ca}}$ & $1.55 \pm 0.21^{\mathrm{Aa}}$ & $7.18 \pm 0.97^{\mathrm{B}}$ & $3.91 \pm 0.23^{\mathrm{Ca}}$ \\
2-Jejunum & & & & \\
GLUT2 (AU) & $1.00 \pm 0.40^{\mathrm{Aa}}$ & $1.01 \pm 0.33^{\mathrm{Aa}}$ & $0.88 \pm 0.35^{\mathrm{Aa}}$ & $3.39 \pm 0.22^{\mathrm{B}}$ & $0.28 \pm 0.04^{\mathrm{Ab}}$ \\
SGLT1(AU) & $1.00 \pm 0.30^{\mathrm{Aa}}$ & $1.28 \pm 0.52^{\mathrm{a}}$ & $0.47 \pm 0.02^{\mathrm{Aa}}$ & $2.35 \pm 0.86^{\mathrm{Bb}}$ & $1.28 \pm 0.22^{\mathrm{a}}$ \\
PepT1 (AU) & $1.00 \pm 0.25^{\mathrm{Aa}}$ & $3.53 \pm 0.67^{\mathrm{Ca}}$ & $2.02 \pm 0.29^{\mathrm{Ab}}$ & $5.23 \pm 0.66^{\mathrm{B}}$ & $2.51 \pm 0.68^{\mathrm{Cb}}$ \\
\hline
\end{tabular}

significantly increased body weight and improved the feed conversion ratio of broiler chickens [8]. The beneficial effect of oregano essential oils may be attributed to the antimicrobial activity of phenolic compounds [13]. Lee et al. indicated that carvacrol, a component of essential oils, improved the FCR of broilers, and this could be connected with the increase of feed utilization efficiency [14]. Furthermore, Windisch et al. reported that phytogenic compounds may specifically enhance the activities of digestive enzymes and nutrient absorption [3]. Therefore, dietary feeding of oregano essential 
oils may improve the intestinal healthy and digestibility of the feeds and thus improve the performance of laying hens.

Furthermore, it is important to consider that several phytogenic product feed additives have a potential impact on the intestinal microflora either directly or indirectly [15]. In the current study, oregano essential oils supplementation of diets demonstrated a beneficial effect on the gut flora of laying hens. These findings are in compliance with the previous reports [7] [16]. These researchers found that oregano had antibacterial activity against E. coli and Salmonella. The broad antimicrobial activity may be due to the presence of thymol and carvacrol, the major active components of oregano essential oils. Previous studies have indicated that the antibacterial mechanism of carvacrol and thymol may be similar in that they increase the permeability of the cytoplasmic membrane by disrupting bacterial outer membranes, which leads to ATP leaking out of the cell. Carvacrol can also inhibit ATPase and thus be able to influence the proliferation of bacteria [17]. Moreover, carvacrol also has a stimulating effect on Lactobacillus proliferation. In the present study, the dietary treatments also significantly increased the Lactobacillus counts.

In addition, it is reasonable to study digestive enzymes existing in the small intestine and pancreas to reveal the effects of oregano essential oils on digestive function, as major nutrient digestive processes occur in these areas. It has been reported that the addition of essentialoilss including thymol, one of the main components of oregano essential oils, markedly increased the amylase activity in the intestinal digesta at $\mathrm{d} 21$ in broilers [14]. Similar to our results, Jamroz et al. observed the use of plant extracts containing carvacrol and other active substances enhanced the activities of pancreas $\alpha$-amylase and $\alpha$-amylase and lipase in the intestine tissues of older chickens [18]. Similarly, Hashemipour et al. proved that carvacrol and thymol could increase intestinal trypsin and lipase activities in broilers at $24 \mathrm{~d}$ of age [19].

Data from the intestinal flora have demonstrated that oregano essential oils exerted a positive impact on Lactobacillus and Bifidobacterium in the cecum. Such changes in intestinal microbiology with oregano essential oils might contribute to the observed effects on digestive enzyme activities. Previous studies have reported that the Bifidobacterium and Lactobacillus colonizing the intestine can deliver enzymes, which then leads to increased digestive enzyme activity in the intestines [20]. Moreover, Hashemipour et al. also postulated that the use of phytogenic product would stimulate the secretion of intestinal digestive enzymes and enhance the digestion of nutrients under certain circumstances [19]. Therefore, the results reported here indicate that the addition of oregano essential oils to the diet of laying hens enhanced intestinal digestive function.

Both crypt depth and villous height are important indicators of chicken digestive health and related to the absorptive capacity of intestinal mucous membrane directly. Moreover, the villous: crypt ratio is likely an indicator of the digestive capacity of gut. Our results are in compliance with the research of Perić et al. who found that adding phytogenic additives in the diet of 42-day-old chickens resulted in an increase in the villous height [21]. Similarly, Betancourt et al. demonstrated that diet supplementation with 200 ppm active essential $O$. vulgare L. resulted in a significant increase in villous height at 3 days and slightly decreased crypt depth and increased the villous: crypt ratio in 7-day-old 
chickens [22]. Our study revealed a significant increase of the villous: crypt ratio. These findings indicate that the addition of oregano essential oils to the diet of laying hens enhanced the digestive and absorptive capacity of the intestinal mucous membrane.

The absorption of glucose is mediated by SGLT1, in a $\mathrm{Na}^{+}$-dependent manner, which transports glucose and galactose into the enterocyte [23]. In addition, the exit of glucose, galactose and fructose across the basolateral membrane is facilitated by the transporter GLUT2, which is dependent on the transmembrane concentration gradient [24]. PepT1 is the peptide transporter, which transports divides- and tripeptides into the cell. The PepT1 pathway is a major mechanism for the absorption of intestinal products of protein digestion. Gilbert demonstrated that gene expression of the nutrient transporter is responsive to various factors, including dietary manipulation, genetic selection, and developmental stage [25]. These strategies can be used to enhance nutrient utilization by improving dietary formulation, leading to improved chicken performance. Our study found that the addition of $100 \mathrm{mg} / \mathrm{kg}$ oregano essential oils resulted in a significant increase in SGLT1, GLUT2 and PepT1 mRNA expression, which improved the glucose and protein absorption capacity. A previous study reported that long-term luminal glucose exposure can increase SGLT1 activity in enterocytes and dipeptides themselves, presumably by stimulating gene expression of PepT1 to promote increased dipeptide transport [26]. Therefore, the increase in SGLT1, GLUT2 and PepT1 mRNA expression in the present study may be due to the increased concentration of glucose and peptide in the gut. Furthermore, the nutrition increase may be related to the improved digestive enzyme activity and intestinal morphology.

Colistin (polymyxin E) is a polymyxin antibiotic produced by certain strains of Paenibacillus polymyxa var. colistinus. Recently, the researchers found evidence of transferable resistance to the polymyxin drug colistin in bacteria isolated from pig and poultry in China [27]. The Chinese government has launched a risk assessment on the use of colistin in animal feed and will limit or stop using polymixins in agriculture. Thus, we chose colistin as an antibiotic control. The results proved that dietary inclusion of oregano essential oils increased the laying performance and improved gut microflora, intestinal morphology and nutrient absorption in laying hens. Therefore, oregano essential ilia an ideal herbal antibiotic alternative in the laying hens.

\section{Conclusion}

In conclusion, oregano essential oil enhanced average egg weight and feed efficiency on laying hens. And the additive increased the number of intestinal Bifidobacterium and Lactobacillus and the number of intestinal Escherichia coli and Salmonella decreased. Also the additive increased digestive enzyme activities and improved the intestinal morphology. Furthermore, the gene expression levels of GLUT2, PepT1 and SGLT1 in the duodenum and jejunum were significantly increased. Dietary inclusion of oregano essential oils increased the laying performance and improved nutrient absorption in laying hens.

\section{Acknowledgements}

This work was founded by National Natural Science Foundation of China (Grant Nos. 
31272624, 31402157 and 31472249), the University Nursing Program for Young Scholars with Creative Talents in Heilongjiang Province (UNPYSCT-2015087), and the Startup Foundation for the Doctors in Heilongjiang Bayi Agricultural University (XYB2014-12), the Guidance Program for Science and Technology Development in Daqing city (zd-2016-094).

\section{References}

[1] Burgat, V. (1991) Residues of Drugs of Veterinary Use in Food. Revue du Praticien, 41, 985-990.

[2] Castanon, J.I. (2007) History of the Use of Antibiotics as Growth Promoters in European Poultry Feeds. Poultry Science, 86, 2466-2471. https://doi.org/10.3382/ps.2007-00249

[3] Windisch, W., Shedle, K., Plitzner, C. and Kroismayr, A. (2008) Use of Phytogenic Products as Feed Additives for Swine and Poultry. Journal of Animal Science, 86, E140-E148. https://doi.org/10.2527/jas.2007-0459

[4] Zotti, M., Colaianna, M., Morgese, M.G., Tucci, P., Schiavone, S., Avato, P. and Trabace, L. (2013) Carvacrol: From Ancient Flavoring to Neuromodulatory Agent. Molecules, 18, 6161-6172. https://doi.org/10.3390/molecules 18066161

[5] Mooyottu, S., Kollanoor-Johny, A., Flock, G., Bouillaut, L., Upadhyay, A., Sonenshein, A.L. and Venkitanarayanan, K. (2014) Carvacrol and Trans-Cinnamaldehyde Reduce Clostridium Difficile Toxin Production and Cytotoxicity in Vitro. International Journal of Molecular Sciences, 15, 4415-4430. https://doi.org/10.3390/ijms15034415

[6] Espina, L., Pagán, R., López, D. and García-Gonzalo, D. (2015) Individual Constituents from Essential Oils Inhibit Biofilm Mass Production by Multi-Drug Resistant Staphylococcus aureus. Molecules, 20, 11357-11372. https://doi.org/10.3390/molecules200611357

[7] Ouwehand, A.C., Tiihonen, K., Kettunen, H., Peuranen, S., Schulze, H. and Rautonen, N. (2010) In Vitro Effects of Essential Oilss on Potential Pathogens and Beneficial Members of the Normal Microbiota. Veterinary Medicine, 55, 71-78.

[8] Roofchaee, A., Irani, M., Ebrahimzadeh, M.A. and Akbari, M.R. (2011) Effect of Dietary Oregano (Origanum vulgare L.) Essential Oils on Growth Performance, Cecal Microflora and Serum Antioxidant Activity of Broilser Chickens. African Journal of Biotechnology, 10, 6177-6183.

[9] Hashemipour, H., Kermanshahi, H., Golian, A. and Veldkamp, T. (2013) Effect of Thymol and Carvacrol Feed Supplementation on Performance, Antioxidant Enzyme Activities, Fatty Acid Composition, Digestive Enzyme Activities, and Immune Response in Broilser Chickens. Poultry Science, 92, 2059-2069. https://doi.org/10.3382/ps.2012-02685

[10] Hong, J.C., Steiner, T., Aufy, A. and Lien, T.F. (2012) Effects of Supplemental Essential Oils in Growth Performance, Lipid Metabolites and Immunity, Intestinal Characteristics, Microbiota and Carcass Traits in Broilsers. Livestock Science, 144, 253-262. https://doi.org/10.1016/j.livsci.2011.12.008

[11] Radwan, N.L., Hassan, R.A., Qota, E.M. and Fayek, H.M. (2008) Effect of Natural Antioxidant on Oxidative Stability of Eggs and Productive and Reproductive Performance of Laying Hens. International Journal of Poultry Science, 7, 134-150. https://doi.org/10.3923/ijps.2008.134.150

[12] Yannakopoulos, A.L. and Tserveni-Gousi, A.S. (1986) Quality Characteristics of Quail Eggs. British Poultry Science, 27, 171-176. https://doi.org/10.1080/00071668608416870

[13] Bozin, B., Mimica-Dukic, N., Simin, N. and Anackov, G. (2006) Characterization of the Volatile Composition of Essential Oilss of Some Lamiaceae Spices and the Antimicrobial and Activities of the Entire Oilss. Journal of Agricultural and Food Chemistry, 54, 1822- 
1828. https://doi.org/10.1021/jf051922u

[14] Lee, K.W., Everts, H., Kappert, H.J., Frehner, M., Losa, R. and Beynen, A.C. (2003) Effects of Dietary Essential Oils Components on Growth Performance, Digestive Enzymes and Lipid Metabolism in Female Broilser Chickens. British Poultry Science, 44, 450-457. https://doi.org/10.1080/0007166031000085508

[15] Cowan, M.M. (1999) Plant Products as Antimicrobial Products. Clinical Microbiology Reviews, 12, 564-582.

[16] Mathlouthi, N., Bouzaienne, T., Oueslati, I., Recoquillay, F., Hamdi, M., Urdaci, M. and Bergaoui, R. (2012) Use of Rosemary, Oregano, and a Commercial Blend of Essential Oilss in Broilser Chickens: In Vitro Antimicrobial Activities and Effects on Growth Performance. Journal of Animal Science, 90, 813-823. https://doi.org/10.2527/jas.2010-3646

[17] Gill, A.O. and Holley, R.A. (2006) Disruption of Escherichia coli, Listeria monocytogenes and Lactobacillus sakei Cellular Membranes by Plant Oilss Aromatics. International Journal of Food Microbiology, 108, 1-9. https://doi.org/10.1016/j.ijfoodmicro.2005.10.009

[18] Jamroz, D., Wiliczkiewicz, A., Wertelecki, T., Orda, J. and Skorupińska, J. (2005) Use of Active Substances of Plant Origin in Chicken Diets Based on Maize and Locally Grown Cereals. British Poultry Science, 46, 485-493. https://doi.org/10.1080/00071660500191056

[19] Hashemipour, H., Kermanshahi, H., Golian, A. and Veldkamp, T. (2013) Effect of Thymol and Carvacrol Feed Supplementation on Performance, Antioxidant Enzyme Activities, Fatty Acid Composition, Digestive Enzyme Activities, and Immune Response in Broilser Chickens. Poultry Science, 92, 2059-2069. https://doi.org/10.3382/ps.2012-02685

[20] Sissons, J.W. (1989) Potential of Probiotic Organisms to Prevent Diarrhea and Promote Digestion in Farm Animals-A Review. Journal of the Science of Food and Agriculture, 49, 1-13. https://doi.org/10.1002/jsfa.2740490102

[21] Perić, L., Milošević, N., Žikić, D., Bjedov, S., Cvetković, D., Markov, S., Mohnl, M. and Steiner, T. (2010) Effects of Probiotic and Phytogenic Products on Performance, Gut Morphology and Cecal Microflora of Broilser Chickens. Archiv fur Tierzucht, 53, 350-359.

[22] Betancourt, L.L., Ariza, C.J. and Afanador, G. (2012) Effects of Supplementation with Oregano Essential Oils on Ileal Digestibility, Intestinal Histomorphology, and Performance of Broilser Chickens. Revista Colombiana de Ciencias Pecuarias, 25, 240-251.

[23] Wright, E.M. and Turk, E. (2004) The Sodium/Glucose Cotransporter Family SLC5. European Journal of Physiology, 447, 510-518. https://doi.org/10.1007/s00424-003-1063-6

[24] Uldry, M. and Thorens, B. (2004) The SLC2 Family of Facilitated Hexose and Polyol Transporters. European Journal of Physiology, 447, 480-489. https://doi.org/10.1007/s00424-003-1085-0

[25] Gilbert, E.M. (2008) Dietary and Developmental Regulation of Nutrient Transporter Gene Expression in the Small Intestine of Two Lines of Broilsers. PhD Thesis, Virginia Polytechnic Institute and State University, Blacksburg.

[26] Thamotharan, M., Bawani, S.Z., Zhou, X.D., Zhou, X. and Adibi, S.A. (1998) Mechanism of Dipeptide Stimulation of Its Own Transport in a Human Intestinal Cell Line. Proceedings of the Association of American Physicians, 110, 361-368.

[27] Liu, Y.Y., Wang, Y., Walsh, T.R., Yi, L.X., Zhang, R., Spencer, J., Doi, Y., Tian, G., Dong, B., Huang, X., Yu, L.F., Gu, D., Ren, H., Chen, X., Lv, L., He, D., Zhou, H., Liang, Z., Liu, J.H. and Shen, J. (2015) Emergence of Plasmid-Mediated Colistin Resistance Mechanism MCR1 in Animals and Human Beings in China: A Microbiological and Molecular Biological Study. Lancet Infectious Diseases, 16, 161-168.

https://doi.org/10.1016/S1473-3099(15)00424-7 
Submit or recommend next manuscript to SCIRP and we will provide best service for you:

Accepting pre-submission inquiries through Email, Facebook, LinkedIn, Twitter, etc. A wide selection of journals (inclusive of 9 subjects, more than 200 journals)

Providing 24-hour high-quality service

User-friendly online submission system

Fair and swift peer-review system

Efficient typesetting and proofreading procedure

Display of the result of downloads and visits, as well as the number of cited articles Maximum dissemination of your research work

Submit your manuscript at: http://papersubmission.scirp.org/

Or contact ajmb@scirp.org 